\section{(2) OPEN ACCESS}

\title{
The state of global abortion data: an overview and call to action
}

\author{
Anna Popinchalk (D), Cynthia Beavin, Jonathan Bearak (D)
}

Guttmacher Institute, New York, New York, USA

\section{Correspondence to} Anna Popinchalk, Guttmacher Institute, New York, New York, USA; apopinchalk@guttmacher. org

Received 11 March 2021 Revised 23 April 2021

Accepted 27 April 2021
Check for updates

(c) Author(s) (or their employer(s)) 2021. Re-use permitted under CC BY-NC. No commercial re-use. See rights and permissions. Published by BMJ.

To cite: Popinchalk A, Beavin C, Bearak J. BMJ Sex Reprod Health Published Online First: [please include Day Month Year]. doi:10.1136/ bmjsrh-2021-201109
Abortion, an experience shared by tens of millions of people around the world, is an important component of sexual and reproductive health (SRH) care. Data on abortion incidence is needed to examine disparities in people's ability to safely terminate a pregnancy. Abortion, however, is legally restricted in much of the world and often stigmatised regardless of legal status, making it challenging to measure and document. This contributes to disparities in understanding the SRH needs of people in different contexts around the world.

Due to the difficulty in measuring abortion, we developed model-based estimates following a clear and transparent protocol. ${ }^{1}$ These estimates utilised all global data on the number of abortions by country by year. ${ }^{2}$ While these are the most comprehensive estimates currently available, our data collection and research underscored that empirical data on abortion incidence are scarce and of variable quality. To address these gaps, there is an urgent need for investing in robust abortion data collection systems and research.

Data on abortion come from three main sources: official statistics, surveys of women, and scientific studies. However, the legal status and stigmatisation of abortion influences the quality of data in a country. These affect whether data are available and, if available, the degree to which they may be underreported. While threats to the accuracy of abortion data apply in some degree to all data sources and legal settings, some concerns are more relevant to specific sources.

Among high-income countries where abortion is broadly legal, official statistics on the annual number of abortions are the primary source of abortion data. Official statistics, however, may not capture all abortions due to different country reporting requirements, whether reporting is mandated in the public and/ or private sector, and non-compliance of providers. Stigma may also impact official statistics by causing individuals to seek abortions outside of the formal health sector, the latter affected by the increasing availability of misoprostol.

Most women of reproductive age live in low- and middle-income countries where abortion is legally restricted; and even among countries where abortion is broadly legal, like India and China, official statistics are generally unavailable or incomplete. When abortion data are available in these settings the sources are usually surveys of women or scientific studies. Stigma can increase women's reluctance to self-report their abortion experiences. As a result, direct reports from surveys may not provide the true number of abortions, but they do provide important information that abortions occur in these settings. Scientific studies are an alternative way to measure abortion incidence, and various methodologies have been developed including indirect estimation techniques and social networkbased measures. $^{3}$

Sources of abortion data also vary in the frequency with which they are published. Official statistics are often released annually whereas surveys or scientific studies, because of their cost, may only be conducted in a country once or, if repeated, may only occur every few years. As a result, there is great variation across regions and between countries with liberal and restrictive laws in whether abortion data are available, whether trend data exist, and whether the data available are current.

From our data collection process (further described in Bearak et al, 20204) in total we collected 3312 observations (where an observation is an annual number of abortions for a country from one source) of abortion data from 1990 to 2018 from a total of 106 countries. [NB. Due to other data inputs used in our model from the United Nations Population Division, our data collection process only sought to collect data for 195 


\section{Editorial}

Table 1 Abortion data availability by type, time period, and Sustainable Development Group region

\begin{tabular}{|c|c|c|c|c|c|c|c|c|c|}
\hline \multirow[b]{2}{*}{ Region } & \multirow[b]{2}{*}{ Data type } & \multicolumn{2}{|l|}{ 1990-1999 } & \multicolumn{2}{|l|}{ 2000-2009 } & \multicolumn{2}{|l|}{ 2010-2018 } & \multicolumn{2}{|l|}{ Total } \\
\hline & & Observations & $\begin{array}{l}\text { Countries } \\
\text { and } \\
\text { territories }\end{array}$ & Observations & $\begin{array}{l}\text { Countries } \\
\text { and } \\
\text { territories }\end{array}$ & Observations & $\begin{array}{l}\text { Countries } \\
\text { and } \\
\text { territories }\end{array}$ & Observations & $\begin{array}{l}\text { Countries } \\
\text { and } \\
\text { territories }\end{array}$ \\
\hline \multirow{6}{*}{$\begin{array}{l}\text { Sub-Saharan } \\
\text { Africa } \\
\text { ( } 50 \text { countries) }\end{array}$} & Study & 1 & 1 & 6 & 5 & 9 & 9 & 16 & \\
\hline & Survey & 1 & 1 & 5 & 2 & 5 & 3 & 11 & \\
\hline & Official statistics & 14 & 3 & 46 & 5 & 36 & 7 & 96 & \\
\hline & Complete & 4 & 1 & 19 & 1 & 15 & 2 & 38 & \\
\hline & Incomplete & 10 & 2 & 27 & 4 & 21 & 5 & 58 & \\
\hline & Total & 16 & & 57 & & 50 & & 123 & 20 \\
\hline \multirow{6}{*}{$\begin{array}{l}\text { West Asia and } \\
\text { North Africa } \\
\text { ( } 25 \text { countries) }\end{array}$} & Study & 1 & 1 & 0 & 0 & 0 & 0 & 1 & \\
\hline & Survey & 3 & 2 & 7 & 4 & 4 & 3 & 14 & \\
\hline & Official statistics & 71 & 5 & 97 & 5 & 70 & 4 & 238 & \\
\hline & Complete & 0 & 0 & 0 & 0 & 0 & 0 & 0 & \\
\hline & Incomplete & 71 & 5 & 97 & 5 & 70 & 4 & 238 & \\
\hline & Total & 75 & & 104 & & 74 & & 253 & 7 \\
\hline \multirow{6}{*}{$\begin{array}{l}\text { Central and } \\
\text { South Asia } \\
\text { (14 countries) }\end{array}$} & Study & 1 & 1 & 2 & 2 & 5 & 4 & 8 & \\
\hline & Survey & 3 & 3 & 2 & 2 & 3 & 2 & 8 & \\
\hline & Official statistics & 75 & 8 & 83 & 8 & 76 & 6 & 234 & \\
\hline & Complete & 0 & 0 & 0 & 0 & 0 & 0 & 0 & \\
\hline & Incomplete & 75 & 8 & 83 & 8 & 76 & 6 & 234 & \\
\hline & Total & 79 & & 87 & & 84 & & 250 & 10 \\
\hline \multirow{6}{*}{$\begin{array}{l}\text { East and } \\
\text { Southeast Asia } \\
\text { (17 countries) }\end{array}$} & Study & 2 & 2 & 2 & 2 & 0 & 0 & 4 & \\
\hline & Survey & 3 & 1 & 14 & 4 & 8 & 2 & 25 & \\
\hline & Official statistics & 82 & 8 & 103 & 7 & 82 & 8 & 267 & \\
\hline & Complete & 50 & 5 & 61 & 3 & 45 & 3 & 156 & \\
\hline & Incomplete & 32 & 3 & 42 & 4 & 37 & 5 & 111 & \\
\hline & Total & 87 & & 119 & & 90 & & 296 & 11 \\
\hline \multirow{6}{*}{$\begin{array}{l}\text { Latin America } \\
\text { (38 countries) }\end{array}$} & Study & 4 & 4 & 9 & 7 & 0 & 0 & 13 & \\
\hline & Survey & 1 & 1 & 0 & 0 & 1 & 1 & 2 & \\
\hline & Official statistics & 57 & 8 & 119 & 12 & 70 & 12 & 246 & \\
\hline & Complete & 13 & 3 & 43 & 4 & 26 & 4 & 82 & \\
\hline & Incomplete & 44 & 5 & 76 & 8 & 44 & 8 & 164 & \\
\hline & Total & 62 & & 128 & & 71 & & 261 & 17 \\
\hline \multirow{6}{*}{$\begin{array}{l}\text { Europe and } \\
\text { Northern } \\
\text { America* }^{*} \\
\text { (42 countries) }\end{array}$} & Study & 10 & 1 & 10 & 1 & 8 & 1 & 28 & \\
\hline & Survey & 8 & 4 & 3 & 3 & 1 & 1 & 12 & \\
\hline & Official statistics & 640 & 42 & 794 & 39 & 537 & 38 & 1971 & \\
\hline & Complete & 416 & 22 & 485 & 22 & 355 & 24 & 1256 & \\
\hline & Incomplete & 224 & 20 & 309 & 17 & 182 & 14 & 715 & \\
\hline & Total & 658 & & 807 & & 546 & & 2011 & 38 \\
\hline \multirow{6}{*}{$\begin{array}{l}\text { Australia and } \\
\text { New Zealand } \\
\text { (two countries) }\end{array}$} & Study & 10 & 1 & 4 & 1 & 0 & 0 & 14 & \\
\hline & Survey & 0 & 0 & 0 & 0 & 0 & 0 & 0 & \\
\hline & Official statistics & 31 & 2 & 40 & 2 & 29 & 2 & 100 & \\
\hline & Complete & 11 & 1 & 20 & 1 & 16 & 1 & 47 & \\
\hline & Incomplete & 20 & 1 & 20 & 1 & 13 & 1 & 53 & \\
\hline & Total & 41 & & 44 & & 29 & & 114 & 2 \\
\hline
\end{tabular}

Continued 
Table 1 Continued

\begin{tabular}{|c|c|c|c|c|c|c|c|c|c|}
\hline \multirow[b]{2}{*}{ Region } & \multirow[b]{2}{*}{ Data type } & \multicolumn{2}{|l|}{ 1990-1999 } & \multicolumn{2}{|l|}{ 2000-2009 } & \multicolumn{2}{|l|}{ 2010-2018 } & \multicolumn{2}{|l|}{ Total } \\
\hline & & Observations & $\begin{array}{l}\text { Countries } \\
\text { and } \\
\text { territories }\end{array}$ & Observations & $\begin{array}{l}\text { Countries } \\
\text { and } \\
\text { territories }\end{array}$ & Observations & $\begin{array}{l}\text { Countries } \\
\text { and } \\
\text { territories }\end{array}$ & Observations & $\begin{array}{l}\text { Countries } \\
\text { and } \\
\text { territories }\end{array}$ \\
\hline \multirow{6}{*}{$\begin{array}{l}\text { Oceania } \\
\text { (excluding } \\
\text { Australia and } \\
\text { New Zealand) } \\
\text { (eight countries) }\end{array}$} & Study & 0 & 0 & 0 & 0 & 0 & 0 & 0 & \\
\hline & Survey & 0 & 0 & 0 & 0 & 0 & 0 & 0 & \\
\hline & Official statistics & 0 & 0 & 4 & 1 & 2 & 1 & 6 & \\
\hline & Complete & 0 & 0 & 0 & 0 & 0 & 0 & 0 & \\
\hline & Incomplete & 0 & 0 & 4 & 1 & 2 & 1 & 6 & \\
\hline & Total & 0 & & 4 & & 2 & & 6 & 1 \\
\hline
\end{tabular}

Country columns are not mutually exclusive, which is why they are only totalled for all time periods and sources.

*In the United Kingdom of Great Britain and Northern Ireland (UK), abortion incidence is reported separately for England and Wales, and Scotland. As a result, for the total number of countries in Europe and Northern America we count these two reporting groupings as separate countries.

countries and territories. The percentages cited here are based on this denominator.] Vast regional disparities exist in abortion data availability (table 1). Europe and northern America accounted for 60\% (2011) of all observations, due to $90 \%$ of countries in the region collecting, and the majority publishing, annual abortion statistics. All other regions (except Australia and New Zealand) had significantly fewer observations available for a much smaller proportion of countries in the region. In sub-Saharan Africa and Latin America, abortion data were available for $40 \%$ and $45 \%$ of countries in the regions, respectively. While sub-Saharan Africa had 123 observations compared with 261 in Latin America, more studies and surveys have been conducted in sub-Saharan Africa since 2010, whereas in Latin America no scientific studies have been conducted since 2009 .

Regions may be burdened with both limited and incomplete abortion data. West Asia and North Africa is the gravest example of this, where all 238 observations based on official statistics are incomplete, and additional abortion counts are available from only one study and 14 surveys since 1990. In Central and South Asia, all official statistics are also incomplete. Surveys and scientific studies therefore constitute most of our knowledge on abortion outside of Europe and Northern America. Discouragingly, countries in Europe, especially Eastern Europe, also have incomplete official statistics.

Current variation in abortion data availability ultimately causes stakeholders to know vastly more about abortion in some settings and countries compared with others. This results in inequities in understanding the SRH care needs and experiences of people, and limits the evidence available to support policy and programmatic decisions. However, abortion incidence data are essential for countries to understand and improve the SRH of their populations and can be an important tool in increasing access to safe abortion through legal or healthcare service reform. ${ }^{56}$

This also poses significant research challenges, as it can be difficult to quantify the degree of underreporting in official statistics. Recently published model-based estimates, ${ }^{7}$ which included a newly developed data classification process to increase transparency and consistency in incorporating information on abortion data sparsity and quality, offer an important methodological step forward in estimating and comparing the incidence of abortion around the world. Estimates, however, fundamentally depend on solid empirical data. Without them, estimates for certain regions and countries will continue to have large uncertainty due to the lack of quality data over time.

Abortion data availability can be improved in a variety of ways, although the legal status of abortion and capacity of health information systems dictate what data collection approaches are feasible for obtaining good quality data. Where abortion is highly restricted and/or it is not feasible for governments to collect data on abortion, investing in country-level surveys and scientific studies is important. However, regardless of the source of abortion data, stigma will continue to hinder the accuracy and completeness of the data, and current efforts to reduce abortion stigma, such as community and provider messaging training, storytelling campaigns, and research to assess these interventions, ${ }^{89}$ should be supported and expanded.

From 1990 to 2018, only 54\% of the world's countries had at least one observation of abortion data, regardless of completeness. This underscores the urgent need to invest in robust abortion data collection systems and research, especially in regions and countries where there are limited or no data. Investing in national health information systems and in abortion research will provide evidence on abortion incidence that meets the needs of policymakers, advocates and providers and help them to better serve their populations. Improvements in availability and quality of abortion data will not only contribute to the scientific literature and strengthen modelbased estimates in the future but, most importantly, produce the evidence needed to target investments where they are most needed to improve SRH care globally. 
Correction notice The funding statement has been updated since this article was published online.

Contributors All authors contributed to the conceptualisation and planning of this editorial. AP led the writing of the editorial with comments and edits from $\mathrm{CB}$ and JB. AP edited and revised all subsequent drafts.

Funding This study was funded by UK Aid from the UK Government. The funders of the study had no role in the data collection, data analysis, data interpretation, or writing of this editorial. The corresponding author had full access to all the data in the study and had final responsibility for the decision to submit for publication.

Competing interests None declared.

Patient and public involvement Patients and/or the public were not involved in the design, or conduct, or reporting, or dissemination plans of this research.

Patient consent for publication Not required.

Provenance and peer review Not commissioned; externally peer reviewed.

Data availability statement The data collection process only involved secondary data collection. The published estimates, however, have undergone the World Health Organization country consultation process. The public use dataset of global abortion data is cited and available via the Open Science Framework (OSF).

Open access This is an open access article distributed in accordance with the Creative Commons Attribution Non Commercial (CC BY-NC 4.0) license, which permits others to distribute, remix, adapt, build upon this work noncommercially, and license their derivative works on different terms, provided the original work is properly cited, appropriate credit is given, any changes made indicated, and the use is noncommercial. See: http://creativecommons.org/licenses/by-nc/4. $0 /$.

\section{ORCID iDs}

Anna Popinchalk http://orcid.org/0000-0003-2141-5662

Jonathan Bearak http://orcid.org/0000-0002-3207-1431

\section{REFERENCES}

1 Bearak JM, Popinchalk A, Sedgh G, et al. Pregnancies, abortions, and pregnancy intentions: a protocol for modeling and reporting global, regional and country estimates. Reprod Health 2019;16:36.

2 Popinchalk A, Beavin C, Kwok L. Global abortion incidence dataset. Open Science Framework (OSF), 2021.

3 Singh S, Remez L, Tartaglione A. Methodologies for estimating abortion incidence and abortion-related morbidity: a review. New York, NY;Guttmacher Institute; International Union for the Scientific Study of Population; 2010. http://www.guttmacher. org/pubs/compilations/IUSSP/abortion-methodologies.pdf [Accessed Feb 17, 2021].

4 Bearak JM, Popinchalk A, Ganatra B. Global estimation of unintended pregnancy and abortion using a Bayesian hierarchical random walk model. arXiv:200709246 [stat], 2020. Available: http://arxiv.org/abs/2007.09246 [Accessed Feb 16, 2021].

5 Moore AM, Gebrehiwot Y, Fetters T, et al. The estimated incidence of induced abortion in Ethiopia, 2014: changes in the provision of services since 2008. Int Perspect Sex Reprod Health 2016;42:111-20.

6 Juárez F. La relación anticoncepción, morbilidad y mortalidad materna y el aborto inducido:evidencia científica. In:

Despenalización del aborto en El D. f. Argumentos para La reflexión. PUEG-UNAM/IPAS/GIRE, 2009: 39-47.

7 Bearak J, Popinchalk A, Ganatra B, et al. Unintended pregnancy and abortion by income, region, and the legal status of abortion: estimates from a comprehensive model for 1990-2019. Lancet Glob Health 2020;8:e1152-61.

8 International Planned Parenthood Federation (IPPF). Reducing abortion stigma: global achievements since 2014, 2021. Available: https://www.ippf.org/sites/default/files/Reducing\% 20abortion $\% 20$ stigma $\% 20-\% 20$ Packard $\% 20$ summary $\%$ 20report\%20-\%20English.pdf [Accessed April 20, 2021].

9 Cockrill K, Herold S, Blanchard K, et al. Addressing abortion stigma through service delivery: a white paper. The Sea Change Program, Advancing New Standards in Reproductive Health, and Ibis Reproductive Health, 2013. 